\title{
New Media dan Konflik Ekstrimis Perempuan Indonesia
}

\section{New Media and The Extrimistic Conflict of Indonesia Women}

\author{
Siti Mupida \\ Pascasarjana UIN Sunan Kalijaga Yogyakarta \\ e-mail : mufida260893@gmail.com
}

\author{
Mustolehudin \\ Balai Penelitian dan Pengembangan Agama Semarang \\ e-mail : mustolehuddin@gmail.com
}

Artikel diterima 23 Agustus 2020, diseleksi 13 September 2020 dan disetujui 19 November 2020

Abstrak: Tulisan ini bertujuan menganalisis dampak new media terhadap para perempuan yang aktif berselancar di dunia maya terutama dalam hal ideologi keagamaan yang mengarah pada pemikiran dan gerakan ekstrimis. Penelitian ini menggunakan metode kajian literatur. Data diperoleh dari situs-situs online dan di analisis dengan analisis wacana. Hasil penelitian menunjukkan bahwa, new media memiliki pengaruh besar yang dapat merubah ideologi sekelompok perempuan dari inklusif menjadi ekslusif. Beberapa faktor yang mempengaruhi kelompok perempuan di Indonesia berhaluan ekstrim adalah karena adanya rasa ketidak-adilan, kebutuhan emosional, kemiskinan (faktor ekonomi), ketidakpuasan terhadap pemerintah, dan disebabkan ingin menegakkan khilafah. Ideologi yang dikembangkan oleh situs-situs berhaluan ekstrim adalah seputar narasi hijrah, jihad, khilafah, dan intoleransi.

Kata Kunci: New Media, Perempuan, Ekslusif, Gerakan Ekstrimis 
Abstract: This paper aims to analyze the impact of new media on women who actively surf in cyberspace, especially in terms of religious ideology that leads to extremist thoughts and movements. This research uses literature study method. Data obtained from online sites and analyzed by discourse analysis. The results of the research show that new media has a major influence which can change the ideology of women's groups from inclusive to exclusive. Some of the factors that influence women's groups in Indonesia to take extreme positions are due to a sense of injustice, emotional needs, poverty (economic factors), dissatisfaction with the government, and wanting to establish a caliphate. The ideologies developed by sites with extreme tendencies revolve around the narrative of hijrah, jihad, khilafah, and intolerance.

Keywords: New Media, Women, Exclusive, Extremist Movements 


\section{A. Pendahuluan}

Fenomena penyebaran narasi ekstrimis dan jihadis melalui new media menjadi penanda adanya pola interaksi sosial dan pembicaraan agama melalui kanal-kanal baru yang menyampaikan atau memberi informasi, propaganda, serta penyebaran paham-paham radikal oleh beberapa kelompok ekstrimis dengan mengatas-namakan agama. Meningkatnya aktivisme perempuan dalam tindakan ekstrimisme ini terkait dengan bangkitnya Negara Islam Irak dan Suriah (ISIS) dengan simbol yang mengatasnamakan agama, guna mendirikan khilafah dan negara Islam yang sesungguhnya. Radikalisasi dalam bidang kekerasan merupakan proses adopsi sistem yang mempromosikan aksi kekerasan. Namun, jika ditinjau dalam arti luas radikalisasi dapat berbentuk pemahaman yang menekankan pada perubahan dalam masyarakat ${ }^{1}$.

Berbagai studi tentang new media menerangkan beberapa faktor sebagai penyebab radikalisasi termasuk kondisi ekonomi, kegagalan negara $^{2}$, kolonialisme Barat $^{3}$, masalah identitas, kohesi sosial dan dukungan untuk rezim opresif ${ }^{4}$, politik dan integrasi sosial ekonomi ${ }^{5}$, penghinaan $^{6}$, masalah ideologi, teologi, imaji, dan narasi kekerasan ${ }^{7}$, dan faktor psikologis lainnya ${ }^{8}$. Terdapat beberapa faktor lain yang menjadi penyebab perempuan mudah terpapar paham radikalisme, antara lain, faktor agama, sosial dan budaya yang membuat perempuan Indonesia terpinggirkan. Ekstrimisme bermuara dari sebuah kondisi psikologis (insecurity) yang dimanifestasikan dalam intoleransi.

Kelompok-kelompok teroris ini sangat mahir menggunakan teknologi digital. Mereka mampu bermain di new media, mereka dapat bermain di semua media sosial untuk bisa melakukan propaganda, melakukan perekrutan, melakukan hasutan dan sebagainya. Mereka juga mampu memanfaatkan teknologi digital dan media sosial itu untuk bisa menggalang, merekrut, memengaruhi dan bisa mengajak, terutama remaja, sehingga banyak dari anak-anak yang masih remaja berhasil direkrut untuk ikut bergabung dengan kelompok ISIS yang ada di 
Syiriah. Dalam 25 tahun terakhir, perkembangan teknologi media luar biasa dahsyatnya dalam mengubah dunia digital, terutama dunia Islam.

Aktifitas new media serba tersambung antara komunitas satu dengan komunitas yang lain dan tidak ada lagi batasan, semuanya serba terdigitalisasi. Inilah yang kemudian menimbulkan konsekuensi di masyarakat, termasuk kehidupan politik, dan keagamaan umat Islam. Dinamika keagamaan berkembang begitu cepat, hal ini dapat dilihat dari terjadinya fragmentasi otoritas keagamaan, terjadinya mode-mode produksi pengetahuan keagamaan baru dan juga mendorong tampilnya new religious, new ulama, new audiens yang ikut serta meramaikan perdebatan tentang simbol-simbol agama9. Istilah new religious adalah merupakan sarana yang memudahkan seseorang belajar agama melalui media. Menurut (Jinan 2013) $)^{10}$, new religious adalah ketika seseorang sudah tidak lagi belajar agama ke surau, langgar dan seterusnya, akan tetapi proses belajar agama diperoleh melalui media digital. Kemudian new ulama adalah mereka yang belajar agama tidak melalui otoritas keagamaan seperti pesantren dan madrasah. Kelompok ini belajar agama melalui internet, mereka inilah yang disebut dengan new audiens. Melihat perkembangan teknologi informasi dan komunikasi, maka hal ini menunjukkan bahwa media diseminasi dakwah pada dekade belakangan mengalami pergeseran signifikan dari televisi hingga platform media sosial ${ }^{11}$. Kanal-kanal new media yang mengusung term radikal dapat diimbangi dengan dakwah moderat melalui internet. Selain itu, new media dapat digunakan sebagai sarana penyuluhan agama Islam $^{12}$ ,juga sebagai media membangun moderasi melalui internet ${ }^{13}$.

Pada dasarnya, secara tidak sadar internet telah mengubah pola konsumsi masyarakat terhadap informasi agama, masyarakat sebelum tahun 2000-an biasanya mendapatkan berbagai informasi melalui media cetak, sepertibuku, majalah, dan jurnal, serta melalui pengajian-pengajian di masjid maupun tempat diskusi lainnya. Namun, kini masyarakat telah bermigrasi ke media-media konvergensi yang lebih instan dan kerap menyajikan konten secara parsial. Internet kini menjadi alat pencarian 
informasi agama secara sporadis. Omar Ashour merumuskan bahwa hal yang membedakan gerakan radikal dan moderat terletak pada dukungan terhadap nilai-nilai dan prinsip demokrasi ${ }^{14}$, seperti misalnya legitimasi pluralisme, kebebasan beragama, kebebasan berekspresi, sistem pemilihan umum dan lainnya. Jika kelompok moderat mendukung nilai dan prinsip tersebut, maka kelompok radikal cenderung menolaknya. Di samping itu, proses radikalisasi umumnya berlangsung dari tahap intoleransi, radikalisasi ideologi, dan kemudian radikalisasi perilaku.

Radikalisme dalam penelitian ini dimaknai sebagai sikap dan gerakan yang menginginkan perubahan tatanan sosial-politik secara fundamental melalui narasi-narasi ekstrim yang revolusioner lewat new media dengan sasaran utamanya perempuan dan kaum muda dengan didasarkan pada pemahaman ajaran agama tertentu. Kecepatan serta kemudahan akses informasi yang dimiliki oleh new media membuat kelompok ekstrimis semakin efektif dalam membuat konten radikal secara mudah dan massive. Media sosial merupakan istilah umum yang digunakan untuk berinteraksi dengan sesama manusia yang mencakup platform online dengan berbagai atribut, format dan unsur dalam komunikasi. Media sosial menjadi begitu menarik karena memiliki berbagai unsur dan karakter, sehingga memberi pengaruh yang signifikan pada beberapa aspek di kehidupan dunia nyata, termasuk memberikan stimulasi gerakan sosial dan pemahaman agama ${ }^{15}$.

Hasil penelitian ini membahas tentang pengaruh new media terhadap konflik radikalisasi perempuan dan kaum muda yang dilihat dari spektrum lebih luas. Dinamika politik tidak pernah berhenti di negeri ini. Selalu ada permasalahan dan konflik, kekerasan, terorisme, hingga perang ideologi yang selalu dikaitkan dengan agama, serta menjadikan new media sebagai platform yang membawa nilai baru dalam beragama bagi sebagian masyarakat. Secara spesifik artikel ini akan merujuk pada beberapa gerakan dan aksi jihad Muslim melalui kanal-kanal baru yang ingin membangun negara Islam di Indonesia. Sehingga memudahkan pembaca dalam memahami konsep new media yang menjadi alat 
komunikasi paling rawan untuk penyebaran ideologi propaganda dan paham radikalisme dengan sasaran perempuan dan kaum muda.

Penelitian ini menggunakan metode literature review. Sebagian data penelitian ini diperoleh melalui metode observasi di situs online dan berbagai tayangan televisi dan Youtube, dengan analisis wacana kemudian menginterpretasikan bentuk-bentuk representasi paham radikalisme melalui media sosial. Data yang terkumpul kemudian dipelajari dan dianalisis peneliti dengan menggunakan analisis deskriptif kualitatif.

\section{B. Hasil dan Pembahasan}

\section{Faktor Penyebab Radikalisasi}

Ekstrimisme dan radikalisme yang paling menonjol saat ini adalah berbasiskan agama, yang secara umum didorong oleh eksklusifitas kelompok-kelompokideologis, politik, ras dan suku. Hal ini salah satunya dapat diketahui dari rencana aksi bunuh diri oleh Dian Yulia Novi seorang mantan TKW di Jakarta akhir 2016. Aksi bom bunuh diri yang melibatkan 77 perempuan antara tahun 2015 - 2016 tercatat 44 kasus dan mengakibatkan 400 orang meninggal di dunia termasuk salah satunya di Indonesia. Lebih lanjut ${ }^{16}$ Nuraiyah mengungkapkan bahwa salah satu keterlibatan perempuan melakukan tindakan aksi bunuh diri adalah karena membela martabat perempuan. Tidak dapat dinafikan bahwa golongan yang paling rentan terpapar ekstrimisme dan radikalisme adalah perempuan dan kalangan muda. Agama dan religiusitas umat sering dinilai sebagai faktor yang signifikan bagi lahirnya konflik dan teror sosial, dibandingkan dengan faktor lain. Seseorang yang berpaham radikalisme tidak semerta-merta melalui faktor atau alasan agama, namun adanya faktor sosial, budaya, dan ekonomi ${ }^{17}$. Berbagai konflik sosial yang disebabkan radikalisme dan militansi beragama kembali mengusik kehidupan berbangsa. Radikalisme terjadi pada agama dan kepercayaan lain, serta untuk tujuan yang beragam, mulai dari politik hingga ekonomi, misalnya agama Budha di Myanmar atas isu etnis Rohingya. 
Namun demikian, proses radikalisasi tidak selalu linear, dan cenderung bersifat kompleks. Peter Neumann memahami bahwa tindakan radikal tidak terjadi secara natural, radikalisme dipengaruhi oleh banyak faktor, dan bukan lahir begitu saja ${ }^{18}$. Neumann menyimpulkan pandangan tersebut setelah meneliti gerakan radikalisme di 15 negara. Faktor lain yang mempengaruhi radikalisme yaitu, rasa ketidakadilan, kebutuhan emosional, pertemuan dengan ideologi intoleren radikal, individu yang berpengaruh, dan normalisasi kekerasan. Hal ini dibuktikan pada contoh kasus pengikut ISIS ${ }^{19}$. Umumnya mereka dari latar belakang 'biasabiasa' saja dalam masyarakat. Mereka bukanlah orang yang religius, tidak merasa sukses, dan kurang bergaul. Mereka memiliki kebutuhan emosional (sense belonging) atau terlibat dalam suatu hal yang lebih besar dari dirinya.

Dalam model hierarki, Veldhuis dan Staun mengklasifikasikan faktor makro dan mikro sebagai akar penyebab radikalisasi ${ }^{20}$. Pada faktor makro merupakan kondisi dasar yang dapat melahirkan radikalisasi. Faktor penyebabnya adalah lemahnya integrasi, hubungan internasional, dan kemiskinan. Sedangkan pada ruang lingkup mikro, terbagi dua yaitu yang berhubungan dengan faktor sosial dan faktor individual. Faktor sosial sebagai penyebab radikalisasi adalah identitas sosial, deprivasi relatif, interaksi sosial dan proses group. Sedangkan dalam ruang lingkup individual adalah karakteristik individu dan pengalaman pribadi.

Di samping itu, penelitian yang dilakukan Van de Linde dan Van der Duin diperoleh temuan, setidaknya ada tiga penyebab yang dapat menjelaskan lahirnya radikalisme. Pertama, penyebaran paham sekularisme atau pemisahan agama dan negara dalam masyarakat Muslim. Kedua, pertumbuhan demografi yang memicu lahirnya berbagai perubahan sosial seperti kemiskinan dan keterbelakangan. Ketiga, kondisi ekonomi seperti pengangguran khususnya di kalangan kaum muda (Van de Linde dan Van der Duin, 2011). Di antara berbagai model dan faktor yang menjadi penyebab terjadinya proses radikalisasi yang berhubungan dengan kemiskinan, deprivasi relatif, dan karakteristik individual serta 
pengalaman pribadi, memiliki hubungan yang signifikan dengan peran perempuan ${ }^{21}$.

Faktor lain yang menjadi akar penyebab radikalisme kemajuan teknologi informasi dan komunikasi yang disalahgunakan oleh beberapa pihak dan kelompok. Radikalisme keagamaan bisa hadir dalam genggaman melalui media sosial ${ }^{22}$. Kemajuan perkembangan teknologi informasi menjadi ancaman keutuhan kehidupan berbangsa dan bernegara, salah satunya kemudahan akses internet menjadikan masyarakat semakin mudah menerima informasi tentang gerakan radikalisme, pembuatan bom, dan aksi kejahatan hingga terorisme ${ }^{23}$. Hal ini dipicu karena rasa ketidakpuasan terhadap pemerintah dan ideologi negara, keinginan kelompok ekstrimis yang ingin mendirikan negara Islam dan menegakkan khilafah.

\section{Peran New Media dalam Konflik Radikalisasi Perempuan}

Beberapa dari masyarakat dan kaum muda mencari informasi dan sumber agama maupun hukum melalui teologi dari media baru (teologi on new media). Kondisi tersebut semakin terlihat nyata dengan munculnya internet atau yang disebut dengan new media. Kehadiran media baru dalam dinamika kehidupan manusia menjadi fakta yang tidak terelakkan. Televisi dan media teknologi informasi lainnya jelas memainkan peran penting dalam memfasilitasi kegiatan keagamaan di Indonesia ${ }^{24}$. Pemerintah Indonesia pada tahun 2017 melalui Kominfo melarang peredaran media sosial Telegram di Indonesia. Telegram dianggap menjadi sarang penyebar konten-konten yang berbau radikal. Di samping telegram, terdapat beberapa situs web yang juga dianggap menjadi sarang penyebar paham radikalisme. Pelarangan ini menjadi simbol betapa bahayanya media ketika digunakan sebagai alat menafaskan radikalisme di Indonesia.

Kajian yang dilakukan (Ghifari, Anam, dan Huda) ${ }^{25}$ menegaskan ada tiga tahapan perkembangan dan pola penyebaran paham radikalisme maupun terorisme di dunia cyber. Pertama, pada tahap awal hanya berupa 
penyebaran ideologi melalui fasilitas website ${ }^{26}$. Kedua, pemanfaatan fitur media interaksi seperti pembuatan forum dan chatrooms ${ }^{27}$. Ketiga, penggunaan new media seperti Youtube, Telegram, Facebook, dan Twitter yang semakin populer di generasi milenial. Internet telah mengubah pola konsumsi generasi milenial dan masyarakat terhadap informasi agama. Mereka dulu biasanya mendapatkan informasi melalui media cetak, majalah, dan jurnal, serta melalui pengajian dari ustaz. Namun sekarang, mereka bermigrasi ke media-media konvergensi yang lebih instan dan kerap menyajikan konten secara parsial. Internet menjadi alat pencarian informasi agama secara sporadis ${ }^{28}$.

Beberapa tahun terakhir ini, aksi teror dan radikalisme di Indonesia tidak hanya melibatkan laki-laki saja, namun juga melibatkan perempuan dan kaum muda. Para perempuan ini terlibat paham radikalisme melalui media sosial, dan bahkan menjadi pelaku bom bunuh diri. Contoh kasus anak muda yang terpapar radikalime adalah seperti di alami Dhania dan keluarganya. Pada tahun 2015, Dhania bersama keluarganya pergi ke Suriah untuk mewujudkan keyakinannya tentang kekhalifahan. Dhania mengaku kerap mendapatkan konten berita mengenai propaganda ISIS tanpa mencari benaran informasi tersebut.

Di samping itu, untuk memahami persoalan ini lebih lanjut, dapat mengacu pada dua artikel dari laporan IPAC yang secara khusus membahas mengenai perempuan dan radikalisme. Pertama, laporan IPAC (2017) ${ }^{29}$, "Mothers to Bombers: The Evolution of Indonesian Women Extremists". Kedua, laporan IPAC (2017) ${ }^{30}$, "The Radicalization of Indonesian Women Workers in Hong Kong". Secara umum, laporan IPAC ini mendiskusikan tentang keterlibatan perempuan Indonesia yang dinilai mulai mengambil peran dalam tindak ekstrimisme dan radikalisme, bahkan beberapa dari mereka ingin menjadi pelaku bom bunuh diri.

Penelitian yang dilakukan Eko Saputra ${ }^{31}$ tentang dinamika Gen Z perempuan dan facebook dan kajian Unaesah Rahmah(Unaesah Rahmah 2020) serta laporan IPAC ${ }^{32}$ menjelaskan tentang ‘kombinasi ISIS 
dan teknologi komunikasi sangat berubah dari bagaimana perempuan ekstrimis melihat dirinya'. Fenomena ini muncul setelah ditangkapnya Dian Yulia Novi dan Ika Puspitasari alias Tsamina Salsabila, kedua perempuan ini ditangkap pada tahun 2016, karena diduga berafiliasi dengan ISIS dan bersedia menjadi pelaku bom bunuh diri. Keduanya adalah mantan tenaga kerja wanita (TKW) di luar negeri. Dian disiapkan untuk menjadi pembom bunuh diri di Istana Kepresidenan, sedangkan Ika dilaporkan akan melakukan bom bunuh diri di Bali. Selanjutnya, Tutin Sugiarti, seorang penjual obat-obatan herbal dan terapis pengobatan Islam, yang diduga memfasilitasi perkenalan Dian dengan pemimpin ISIS. Keterlibatan perempuan selanjutnya adalah Arinda Putri Maharani, tersangka otak pelaku bom panci yang menurut pihak kepolisian disiapkan untuk diledakkan oleh Dian, .

Berdasarkan laporan IPAC, penangkapan empat perempuan tersebut memberikan gambaran yang berbeda dengan apa yang menjadi keyakinanjaringan teroris Jema'ah Islamiyah. Jema'ah Islamiyah melarang perempuan ikut berperang, karena kelompok ini lebih mengedepankan perempuan sebagai ibu dan menjadi pendamping pria di medan perang.

Selanjutnya, artikel dari IPAC (2017) ${ }^{33}$, "The Radicalization of Indonesian Women Workers in Hong Kong". Laporan ini menjelaskan tentang adanya upaya radikalisasi terhadap tenaga kerja Indonesia di Hongkong. Perekrutan oleh kaum ekstrimis ini dilakukan secara rahasia, terutama melalui jaringan online. Laporan IPAC ini menegaskan jumlah yang terradikalisasi sejauh ini masih sedikit, namun tetap harus ditangani dengan serius. Ada beberapa faktor yang menjadi daya tarik untuk bergabung dengan kelompok ekstrimisme. Pertama, orang yang punya semacam masalah pribadi yang cukup besar yang mendorong mereka untuk mencari komunitas baru. Atau mencari jalur di mana mereka bisa 'memurnikan diri' melalui agama. Kedua, konflik di Suriah cukup signifikan sebagai faktor atau alasan mengapa orang tertarik untuk menolong korban di Suriah. Mereka mencari bahan-bahan melalui internet, dan ahkhirnya bertemu dengan kelompok-kelompok jihadis. 
Kemudian, tidak sedikit dari mereka yang melakukan e-dating atau mulai berpacaran dengan para pejihad secra online, melalui pertemuan di internet. Dari kedua laporan IPAC ini menjelaskan bagaimana keterlibatan perempuan dengan kelompok ektrimisme. Hal ini terjadi karena perempuan mudah terpengaruh paham radikal melalui peran keluarga, kerabat, majlis kelompok kecil yang tidak jelas haluannya, hingga terpapar paham radikalisme melalui media internet.

Radikalisme dalam situs dan media sosial menjadi persoalan yang serius karena tiga sebab. Pertama, media sosia tersebut merupakan saluran komunikasi baru. Kedua, jangkauannya sangat luas dan bahkan melewati batas-batas negara. Ketiga, media sosial mampu memengaruhi seseorang dengan sangat efektif. Dalam penelitian pusat studi budaya dan Perubahan Sosial (PSBPS) Universitas Muhammadiyah Surakarta bersama Pusat Pengkajian Islam dan Masyarakat (PPIM) UIN Jakarta ${ }^{34}$ (Pusat Studi Budaya dan Perubahan Sosial (PSBPS) Universitas Muhammadiyah Surakarta PPIM UIN Jakarta - UNDP Indonesia 2018) menjelaskan bahwa situs organisasi Islam arus utama (NU Online dan Suara Muhammadiyah) kerap memproduksi narasi-narasi yang menekankan pentingnya integrasi umat, pesan yang menyejukkan.

Terkail hal tersebut, terdapat beberapa situs Islam kontemporer, yaitu (Hidayatullah.com dan Suara Islam) memberitakan permasalahan terkait organisasi dan kelompok yang memiliki kecenderungan pasif terhadap persoalan radikalisme dalam bidang agama. Di samping itu, terdapat beberapa situs non afiliasi, seperti (Eramuslim.com dan VOA-Islam.com) yang sering menyajikan berita dengan narasi-narasi yang mendukung radikalisme (PSBPS \& PPIM, 2017) ${ }^{35}$.

Penelitian tersebut menjelaskan bahwa situs-situs organisasi Islam non-afiliasi itulah yang paling populer di kalangan warganet Indonesia. Hal ini dapat dilihat dari persentase jumlah pengunjung selama bulan Juli-September 2017. Misalnya, total jumlah pengunjung Eramuslim. com sekitar 9,5 juta lebih, dan VOA-Islam.com sekitar 5 juta lebih. 
Dibandingkan dengan pengunjung NU Online 6,5 juta lebih dan Suara Muhammadiyah sekitar 388 ribu lebih. Situs Eramuslim.com dan VOAIslam.com kerap menulis judul yang mengajak sikap intoleransi dan ujaran kebencian. Mereka menulis judul seperti, 'Media Kufar Bakal Juluki Al-Mahdi Teroris', 'Yahudi Zionis, Biang Kerusakan Dunia', 'Muslim Lemah Dibantai di Rohingya, Masih Tak Mau Jihad?'. Mereka juga mengelola situsnya dengan sangat serius untuk menyampaikan pesan-pesan ideologis kepada pembaca. Narasi radikal dan konten yang ditulis di media sosial mudah masuk dan mempengaruhi pembaca serta kaum muda yang masih mencari jati diri.

Narasi-narasi tersebut mampu memengaruhi pembaca sebagai pembenaran dalam melakukan aksi esktrimisme maupun terorisme. Hal ini dapat dilihat dari data yang dihimpun oleh Badan Nasional Penanggulangan Terorisme (BNPT), bahwa terdapat beberapa kasus yang memiliki keterkaitan dan dipengaruhi oleh media internet terhadap pemikiran radikal seseorang hingga menghasilkan aksi terorisme. Pertama, Tengku Akbar Maulana, mahasiswa pintar yang kuliah di Turki (beasiswa) Sekolah Keagamaan Imam Hatib, umur 16 tahun. Ingin berjihad karna melihat photo teman di Facebook yang gagah mengangkat senjata AK 47, serta ajakan teman untuk jihad ke Suriah dan berbai'at dengan ISIS (Film Jihad Selfie, 2016) ${ }^{36}$. Kedua, Ahmad Taufik alias Ofi, tersangka dalam bom Myanmar setelah lama tidak menghadiri pengajian, dan mengaku men-download pengajian dalam bentuk MP3 yang berpaham radikal dari situs internet. Ketiga, Ahmad Azhar Basyir, mengaku banyak mencari artikel di internet tentang bagaimana membuat detonator, sampai akhirnya bagaimana ia menemukan salah satu akun Facebook Salafi jihadi yang mengulas hal tersebut (PSBPS \& PPIM, 2017) ${ }^{37}$. Keempat, Raihan, yang mengaku terpapar konten-konten radikal melalui media sosial pada tahun 2015 bersama 26 keluarganya pergi ke Suriah untuk mewujudkan keyakinannya tentang khilafah (Seminar Nasional, 2019). 


\section{Pentingnya Merespon Radikalisme dari Perspektif Perempuan}

Radikalisme penting dikaji dari perspektif perempuan, karena perempuan rentan dan mudah terpapar paham radikalisme. Hal ini terjadi karena pengaruh lingkungan pertemanan, keluarga, aliran agama, dan jejaring media sosial. Dalam kasus terosisme pada tahun 2016, setidaknya enam perempuan telah ditangkap atas tuduhan terlibat dalam aksi terorisme. Walaupun angka ini terkesan kecil, namun jumlahnya meningkat dibandingkan tahun-tahun sebelumnya. Beberapa nama tersebut antara lain, Dian Yulia Novi, Arinda Putri Maharani, dan Anggi alias Khanza mantan TKW di luar negeri ${ }^{38}$.

Perubahan ini salah satunya disebabkan oleh perubahan strategi ISIS sejak tahun 2013. Sejak posisi yang semakin terdesak di Suriah dan Irak, ISIS mengubah tsrategi perjuangan yakni kegiatan amaliyah yang dilakukan dengan cara apa saja dan dimana saja. Perubahan strategi ini juga memberi ruang lebih terbuka bagi kalangan perempuan untuk lebih aktif sebagai aktor, mulai dari menyebarkan informasi di media sosial untuk menambah simpatisan, merencanakan teror, membuat bahan peledak hingga mengeksekusinya di lapangan ${ }^{39}$.

Sejumlah studi menyebutkan bahwa posisi perempuan dan radikalisme memiliki peran yang tidak selalu sama dengan laki-laki. Misalnya menjadi ibu yang selalu memiliki peran kursial dalam mendidik anak dan menciptakan generasi muda pelaku teroris; pelindung yang berperan dalam menyembunyikan, menyelamatkan serta memberi tempat aman terhadap teroris, dan pejuang (combatants) yang berkontribusi secara aktif dalam aksi-aksi kekerasan radikal, antara lain sebagai penggalang dana, falisitator transaksi, dan pelaku pengeboman ${ }^{40}$. Dalam budaya patriarki, perempuan dinilai memiliki kelebihan tersendiri ${ }^{41}$. Yakni persepsi bahwa perempuan dipandang tidak berbahaya dibandingkan laki-laki.

Namun yang penting dicatat bahwa keterlibatan perempuan dalam proses intoleransi dan radikalisme tidak bisa ditangani dengan cara serupa dengan laki-laki. Hal ini terkait dengan konteks dan pengalaman 
hidup serta relasi gender yang tidak bisa diabaikan begitu saja. Dalam situasi patriarki, perempuan juga cenderung memiliki sikap intoleran jika interaksinya dengan dunia luar terbatas atau dengan kata lain hanya berbeda di level rumah tangga ${ }^{42}$.

Oleh karena itu, ada beberapa faktor mengapa penting merespon radikalisme dari perspektif perempuan. Pertama, perempuan banyak menjadi korban Gender Based Violence selama konflik atau perang. Hal ini dapat dilihat dari kasus yang ada di Irak; kekerasan seksual telah digunakan sebagai bagian dari strategi untuk menyebarkan teror, menganiaya etnis minoritas dan agama, serta menekan komunitas yang menentang ideologi ${ }^{43}$. Kedua, intoleransi di Indonesia menguat, dimana perempuan juga memiliki kecenderungan intoleran ${ }^{44}$. Ketiga, agenda gerakan radikalisme atau ekstrimisme cenderung viktimisasi terhadap perempuan (Wahid Foudation 2018). Keempat, perempuan dianggap second class yang mudah dijadikan instrumen karena patuh, apolitis, dan loyal (Laporan Alvara Research, 2017). Dalam konstruksi masyarakat patriarki, perempuan dipandang mahluk kelas dua yang harus patuh terhadap suami termasuk mengikuti ideologi pasangannya. Di samping itu, perempuan juga dipandang mahluk apolitis, sehingga tidak mudah dicurigai jika mereka membawa misi bahaya. Tidak hanya memainkan peran pendidik, rekuiter, bahkan perempuan mulai dijadikan ' pengantin' untuk melakukan bom bunuh diri.

\section{Radikalisme Perempuan Lewat Media Sosial}

Seperti yang telah dijelaskan penulis, bahwa keterlibatan perempuan terhadap isu radikalisme dapat dilihat dari beberapa perempuan Indonesia yang mengikuti aksi unjuk rasa terhadap pendukung Hizbut Tahrir Indonesia (HTI) atau bisa dilihat dari keterlibatan perempuan pada beberapa aksi lainnya, seperti demo, dan aksi bela Islam $212^{45}$. Ada beberapa faktor yang menjadi penyebab perempuan mudah terpapar paham radikalisme, antara lain, faktor agama, sosial dan budaya yang membuat perempuan Indonesia terpinggirkan. 
Setidaknya ada dua faktor yang menjadi daya tarik perempuan untuk bergabung dengan kelompok ekstrimisme. Pertama, orang yang punya semacam masalah pribadi yang cukup besar yang mendorong mereka untuk mencari komunitas baru. Atau mencari jalur di mana mereka bisa 'memurnikan diri' melalui agama. Kedua, konflik di Suriah cukup signifikan sebagai faktor atau alasan mengapa orang tertarik untuk menolong korban di Suriah. Mereka mencari bahan-bahan melalui internet, dan akhirnya bertemu dengan kelompok-kelompok jihadis. Kemudian, tidak sedikit dari mereka yang melakukan e-dating atau mulai berpacaran dengan para pejihad secra online, melalui pertemuan di internet. Dari kedua laporan IPAC ini menjelaskan bagaimana keterlibatan perempuan dengan kelompok ektrimisme. Hal ini terjadi karena perempuan mudah terpengaruh paham radikal melalui peran keluarga, kerabat, majelis kelompok kecil yang tidak jelas haluannya, hingga terpapar paham radikalisme melalui media internet ${ }^{46}$.

Mediabaru(internet)jugaberfungsisebagaientitasuntukmenyebarkan ajaran agama. Jika dahulu seseorang yang ingin menyebarkan agama harus menempuh dengan jalan kaki, maka sangat berbeda dengan saat ini. Media baru (internet) sudah menyediakan ruang bagi setiap orang, kelompok maupun lembaga yang akan menyebarkan agama. Dengan menggunakan situs online maka seseorang dapat membuat progam penyebaran berupa content keagamaan. Konten yang dibuat tersebut menembus batas ruang, waktu dan berbagai kalangan ${ }^{47}$.

Sebagai contoh dapat kita lihat pada penggunan media online atau Youtube dalam menyebarkan berbagai video dakwah Islam. Jika zaman dahulu, ceramah atau dakwah dilakukan dengan ceramah dari mimbar ke mimbar, maka sekarang cara tersebut dianggap tidak efektif lagi. Penyebaran dakwah dan agama Islam dianggap lebih efektif dengan memanfaatkan media baru atau internet. Selain itu, hasilnya dapat dilihat oleh orang lain dengan jumlah yang tidak terbatas. Penyebaran dakwah melalui internet ini tidak di batasi oleh ruang dan jarak, bahkan dalam 
hitungan detik dapat dijangkau. Hal tersebut menunjukkan bahwa agama dan media memiliki hubungan yang sangat signifikan.

Dakwah sebagai media pembentuk kepribadian (self personality) dan perilaku (attitude) umat harus dihadirkan dengan strategi yang berhaluan kepada pengembangan keberagamaan yang progresif. Progresivitas dakwah mustahil diwujudkan tanpa dukungan media dan strategi dakwah yang kompeten. Seiring dengan munculnya ragam media dan strategi dakwah, eksistensi jurnalistik hadir sebagai salah satu media komunikasi produktif. Di samping strategi dakwah yang telah umum diterima akal sehat, kehadiran jurnalistik menjadi media kontemporer yang dapat menyeimbangi perkembangan zaman (globalization) yang semakin pesat. Kehadiran media jurnalistik dalam dinamika kehidupan manusia menjadi fakta yang tidak terelakkan. Televisi dan media teknologi informasi lainnya jelas memainkan peran penting dalam memfasilitasi kegiatan keagamaan di Indonesia ${ }^{48}$.

Media dan agama memang memiliki relevanasi yang cukup siginifikan. Namun, media tetap tidak dapat dijadikan sebagai agama apapun $^{49}$. Media hanya dapat dijadikan sebagai wasilah atau saluran dalam penyebaran agama (dakwah). Namun, praktik keagamaan harus dikembalikan pada kitab suci yang dimiliki oleh agama tersebut. Sehingga, agama bukan merupakan produk budaya media. Agama dan media memiliki hubungan timbal balik dalam setiap sejarah kehidupan manusia $^{50}$.

Budaya media, dengan segala konsekuensi pengaruh baik dan buruk yang ditimbulkan, merupakan suatu pengaruh atau efek dari media itu sendiri. Sebab dalam dunia modern, arus informasi yang bertebaran di sekitar kita hanya membawa dua pilihan, ambil atau tinggalkan. Bahkan pada tahapan paling ekstrim, rutinitas keagamaan bisa terganggu oleh derasnya arus informasi yang dihasilkan oleh budaya media. Peran agama yang sesungguhnya adalah membuat orang sadar akan fakta (Wahid 2017). Ada ketergantungan yang nyata, antara kebutuhan terhadap informasi dengan pengaruh yang timbul akibat kecemasan 
terhadap media. Dalam kehidupan beragama, mau tidak mau atau suka tidak suka harus menyesuaikan diri dalam menyikapi terjadinya perubahan yang cepat dalam perkembangan arus informasi yang terjadi pada budaya media. Sebab, bersikap menghindar hanya akan membuat kualitas manusia beragama tertinggal dalam segala hal.

Indonesia merupakan kondisi di mana bangsa Indonesia diharapkan mampu bersaing dengan bangsa lain dalam mengatasi berbagai persoalan di tanah air seperti, kemiskinan dan korupsi yang berkepanjangan, serta pengaruh pemahaman ekstrimisme yang dilakukan secara langsung maupun sembunyi-sembunyi. Bahkan, menggunakan media sosial dengan target para pemuda generasi milenial. Menyebarnya pengaruh gerakan Islam di kalangan mahasiswa tidak bisa dipisahkan dari konteks perkembangan gerakan dakwah kampus di Indonesia ${ }^{51}$.

Fenomenaini sejatinya menjadipenandabahwaada pola interaksi sosial dan pembicaraan agama melalui kanal-kanal baru yang menyampaikan atau memberi informasi, propaganda, serta penyebaran paham-paham radikal oleh beberapa kelompok ekstrimis yang mengatasnamakan agama. Kelompok ekstrimis juga mengelola situs dengan sangat serius untuk menyampaikan pesan-pesan ideologisnya kepada pembaca. Meminjam teori 'jarum hipodermik oleh David K. Berlo, hal ini dapat digambarkan sebagai sebuah peluru yang memasuki pikiran khalayak atau pembaca dan kemudian menyuntikkan beberapa pesan khusus. Artinya, situs-situs radikal yang ada di media sosial diibaratkan sebagai obat yang disuntikkan ke dalam pembuluh darah warganet, kemudian nantinya akan beraksi seperti yang diharapkan oleh pengelola situs atau kelompok ekstrimis.

Sebagian besar proses radikalisasi terhadap perempuan dalam jaringan internet ini berlangsusng sangat efektif dan signifikan. Menurut penulis, bahwa internet dan media sosial bagaikan 'ladang radikal' tempat kelompok ekstrimis menyebarkan narasi untuk mencari simpatisan serta merekrut anggota baru dari pengguna internet dan media sosial unntuk bergabung dan berbai'at dengan ISIS. 
Perempuan dan kalangan pemuda Indonesia harus membekali diri dengan sikap moral dan iman yang baik sebagai pertahanan diri untuk mencegah pengaruh dan ancaman dari pihak luar. Ancaman ini berupa pemahaman dan sikap ekstrimisme atau radikalisme yang dapat menjadi acaman serius bagi keutuhan bangsa Indonesia. Penanaman nilai moral bagi kalangan pemuda dapat dimulai melalui pendidikan, literatur keislaman, dan peran keluarga. Keluarga merupakan dasar utama dalam pertahanan menguatkan nilai moral, agar generasi pemuda Indonesia tidak menyimpang dari aturan-aturan negara ${ }^{52}$.

Oleh karena itu, rentetan peristiwa ekstrimisme yang terjadi akhirakhir ini bisa dijadikan momentum bagi pemerintah untuk merencanakan langkah proaktif dalam rangka mempromosikan keterbukaan, keberagaman, integrasi sosial, dan konstruksi identitas di sekolahsekolah dan lembaga pendidikan lainnya di Indonesia. Salah satu langkah yang bisa dilakukan oleh pemerintah untuk mencegah merebaknya terorisme dan paham radikalisme di Indonesia adalah melalui lembaga pendidikan dalam menangkal tumbuh dan berkembangnya sikap toleransi pada kalangan pelajar dan generasi muda lainnya, sehingga dapat menghentikan masuknya pemikiran-pemikiran radikal. Salah satu upaya yang dapat dilakukan adalah Kementerian Agama memasukkan kurikulum berbasis moderasi beragama mulai tingkat dasar sampai perguruan tinggi.

\section{Kesimpulan}

Sebagian besar proses radikalisasi terhadap perempuan dan kaum muda dalam jaringan online atau new media ini berlangsung sangat efektif dan cepat dalam pencarian jati diri. Internet dan media sosial bagaikan 'ladang radikal' tempat teroris dan kelompok ekstrimis menyebarkan berbagai konten dan narasi untuk mencari simpatisan, serta merekrut pengguna internet dan media sosial. Perempuan yang terpapar radikalisme tidak semerta-merta di latar belakangi oleh faktor tunggal, yakni agama. Akan tetapi, adanya faktor lain seperti, ekonomi atau 
kemiskinan, keluarga, sosial, budaya, dan pendidikan. Artikel ini dapat dijadikan acuan pemerintah Indonesia, mengenai upaya yang dapat dilakukan pemerintah dengan memperhatikan pentingnya pengarusutamakan Islam sebagai agama kemanusiaan, yang menjunjung nilainilai kemanusiaan. Pemerintah hendaknya mendorong dan memfasilitasi situs-situs Islam moderat dalam memproduksi konten-konten moderat. Hasil dari penelitian ini diharapkan memperkaya hasil-hasil riset dan kajian dalam isu perempuan, media sosial, intoleransi dan radikalisme di Indonesia. 


\section{Daftar Pustaka}

Aarssen, L. W., \& Crimi, L. (2016). Legacy, leisure and the 'work hardPlay hard' hypothesis. The Open Psychology Journal, 9. Retrieved from aarssenl@queensu.ca, The political psychology of terrorism fears. (pp. 213-226).

Abdullah, Assyari. 2017. “Membaca Komunikasi Politik Gerakan Aksi Bela Islam 212: Antara Politik Identitas Dan Ijtihad Politik Alternatif." An-Nida: Jurnal Pemikiran Islam 41 (2): 202.

Abdurrahman, Muhammad Sufyan. 2020. “Generasi Muda, Agama

Islam, Dan Media Baru: Perilaku Keagamaan Gerakan Shift Pemuda Hijrah Bandung" 20 (April): 46-63.

Annazilli, Haqqi. 2018. "Relasi Antara Agama Dan Media Baru.” Jurnal Ilmiah Syi'ar. https://doi.org/10.29300/syr.v18i2.1677.

AWID (The Association of Women in Devolopment). 2010. Perempuan Dan Radikalisme Di Indonesia, Membangun Ketahanan Masyarakat Melalui Peran Perempuan. Jakarta: AWID.

Cunningham, Karla. 2007. "The Evolving Participation of Muslim Women in Palestine, Chechnya, and the Global Jihadi Movement." In Female Terrorism and Militancy: Agency, Utility, and Organization. https://doi.org/10.4324/9780203937266.

Hanna Azarya Samosir. 2016. "Film Jihad Selfie, Mengungkap Alasan 'Remeh' WNI Gabung ISIS." Https://Www. Cnnindonesia.Com/, 2016. https://www.cnnindonesia.com/ internasional/20160823083014-106-153170/film-jihad-selfiemengungkap-alasan-remeh-wni-gabung-isis.

Ihsan Ali-Fauzi, Zainal Abdin Bagir, Irsyad Rafsadi. 2017. Kebebasan, Toleransi Dan Terorisme Riset Dan Kebijakan Agama Di Indonesia. Jakarta: Pusat Studi Agama dan Demokrasi Yayasan Paramadina.

IPAC. 2017. "THE RADICALISATION OF INDONESIAN WOMEN WORKERS IN HONG KONG." Jakarta. http://www. understandingconflict.org/en/conflict/read/62/The-Radicalisationof-Indonesian-Women-Workers-in-Hong-Kong. 
Jinan, Mutohharun. 2013. "Intervensi New Media Dan Impersonalisasi Otoritas Keagamaan Di Indonesia." Komunikasi Islam 3 (2). http:// jki.uinsby.ac.id/index.php/jki/article/view/31.

Kailani, Najib. 2009. "Kami Adalah Mujahidin Berpedang Pena: Studi Gerakan Dakwah Forum Lingkar Pena Yogyakarta." niversitas Gajah Mada.

Pusat Studi Budaya dan Perubahan Sosial (PSBPS) Universitas Muhammadiyah Surakarta PPIM UIN Jakarta - UNDP Indonesia. 2018. "Situs-Situs Islam: Kontestasi Narasi Radikal Dan Moderat." Jakarta.

Qori’ah, Sityi Maesarotul. 2019. “Keterlibatan Perempuan Dalam Aksi Terorisme Di Indonesia." Sawwa: Jurnal Studi Gender. https://doi. org/10.21580/sa.v14i1.2967.

Siti Mupida. 2019. "Media Baru Dan Konflik Politik Islam Di Indonesia." Jurnal Idarotuna 2 (1): 14-26. http://ejournal.uin-suska.ac.id/index. php/idarotuna/article/viewFile/8185/4327.

- - - 2020. “Wacana Generasi Muda Menuju Indonesia Emas 2045.” Swarakampus.Com, August 2020. http://swarakampus.com/ web/2020/08/04/wacana-generasi-muda-menuju-ind onesiaemas-2045/.

Tessler, Mark. 2002. "Islam and Democracy in the Middle East: The Impact of Religious Orientations on Attitudes toward Democracy in Four Arab Countries." Comparative Politics. https://doi. org/10.2307/4146957.

Unaesah Rahmah. 2020. "Women in Jihad: An Indonesian Context." Counter Terrorist Trends and Analyses 12 (4): 21-26.

Wahid, Ahfa. 2017. Nasihat-Nasihat Keseharian Gus Dur, Gus Mus, Dan Cak Nun. Yogyakarta: Diva Press.

Wahid Foudation. 2018. Intoleransi Dan Radikalisme Di Kalangan Perempuan. Jakarta: Wahid Foudation.

Zedalis, Debra. 2007. "Beyond the Bombings: Analyzing Female Suicide Bombers." In Female Terrorism and Militancy: Agency, Utility, and Organization. https://doi.org/10.4324/9780203937266. 


\section{Endnotes}

1. Veldhuis Tinka \& Staun Jorgen, Islamist Radicalisation: a Root Cause Model. The Hague: Netherlands Intitute of International Relation Clingendael, 2009,4 .

2. Tighe Evan, Trust in Allah, But Tie Your Camel: The Effect of Radicalized Schooling and state Security on Islamic Terrorism in the Middle East. Diss: University of Georgia, 2011, 9.

3. Gow James, Militancy and Violence in West Africa, Funmi Olonisakin dan Ernst Dijxhoorn (eds.). London: Routledge, 2014, 268.

4. Wing Adrien Katherine and Smith Moca Nigh, "Critical Race Feminism Lifts the Veil: Muslim Women, France, and the Headcraf Ban," UC Davis L Ref, vol. 39 , no. $1,2005,43$.

5. H. Riaz, "Socio-economic marginalization of Muslims in contemporary Australia: Implications for social inclusion," J. Muslim Minor. Aff., 2010, 575.

6. M. Al-lami, "Studies of Radicalisation: State of the Field Report," Polit. Int. Relations Work. Pap., 2009, 4.

7. Letini Pete, "The Transference of Neojihadisme: Toward a Process Theory of Transnational Radicalisation," in Proceeding from the Gtrec International Conference, 2009, 26.

8. Silke Andrew, "Holy Warrios Exploring the Psychological Procces of Jihadi Rdicalization," Eur. J. Criminol., vol. 5, no. 1, 2008, 99.

9. Siti Mupida, "Media Baru dan Konflik Politik Islam di Indonesia," J. Idarotuna, vol. 2, no. 1, 2019, 14-26.

10. Mutohharun Jinan, "Intervensi New Media Dan Impersonalisasi Otoritas Keagamaan Di Indonesia." Komunikasi Islam 3 (2). http://jki.uinsby.ac.id/ index.php/jki/article/view/31, 2013, 322.

11. Triantoro Dony, A. “Ustaz Abdul Somad, Otoritas Karismatik Dan Media Baru.” Universitas Islam Negeri Sunan Kalijaga, 2019, 196.

12. Hasani Ahmad Said, "Penyuluhan Islam di Era Modern: Potret Dakwah Sebagai Media Komunikasi Profetik," J. Bimas Islam, vol. 9, no. 1, 2016, 83-116. 
13. E. Kosasih, "Literasi Media Sosial dalam Pemasyarakatan Sikap Moderasi Beragama," J. Bimas Islam, Vol. 12, No. 2, 2019, 263-296.

14. Ashour, Omar. "Votes and Violence: Islamists and The Processes of Transformation." Developments in Radicalisation and Political Violence, 2009, 6.

15. Iswandi Syahputra, "Media Sosial Dan Prospek Muslim Kosmopolitan: Konstruksi \& Peran Masyarakat Siber Pada Aksi Bela Islam." Jurnal Komunikasi Islam, https://doi.org/10.15642/jki.2018.8.1.19-40, Vol, 0 No. 1, 2018, 19-40.

16. Nava Nuraiyah dan Ihsan Ali-Fauzi, "Suara Yang Terabaikan: Perspektif Gender Dalam Studi-Studi Tentang Kekerasan Teroris Di Indonesia." In Kebebasan, Toleransi, Dan Terorisme Riset Dan Kebijakan Agama Di Indonesia, edited by Ihsan et.all Ali-Fauzi, Jakarta: Pusat Studi Agama dan Demokrasi Yayasan Paramadina, 2017, 263.

17. Sholikin, Ahmad. "Potret Sikap Radikalisme Menuju Pada Perilaku Terorisme Di Kabupaten Lamongan." Journal of Governance, 2018. https://doi. org/10.31506/jog.v3i2.3255, Vol, 3 No. 2, 2018, 184-202.

18. Neumann, P. Prisons and Terrorism: Radicalisation and Deradicalisation in 15 Countries. London: ICSR, 2010, 494.

19. Wahid Foudation. Intoleransi Dan Radikalisme Di Kalangan Perempuan. Jakarta: Wahid Foudation, 2018, 23.

20. Veldhuis Tinka \& Staun Jorgen. Islamist Radicalisation: A Root Cause Model. The Hague: Netherlands Intitute of International Relation Clingendael, 2009,6 .

21. Abdul Ghofur and Sulistiyono Susilo. "Perempuan Dan Narasi Kekerasan: Studi Kritis Peran Gender Dalam Deradikalisasi." Teosofi: Jurnal Tasawuf Dan Pemikiran Islam, https://doi.org/10.15642/teosofi.2015.5.2.431-454, Vol, 5 No. 2, 2015, 431-454.

22. Hanna Azarya Samosir. "Film Jihad Selfie, Mengungkap Alasan 'Remeh' WNI Gabung ISIS." Https://Www.Cnnindonesia.Com/. 2016. https://www. cnnindonesia.com/internasional/20160823083014-106-153170/film-jihadselfie-mengungkap-alasan-remeh-wni-gabung-isis, 2016.

23. Sunarto, PhD, Andang. "Dampak Media Sosial Terhadap Paham 
Radikalisme." Nuansa, 2017. https://doi.org/10.29300/nuansa.v10i2.647, Vol, 9, No. 2, 2017, 126-132.

24. Muzakki,Akh. "IslamasaSymbolicCommodity:TransmittingandConsuming Islam through Public Sermons in Indonesia." In Religious Commodifications in Asia: Marketing Gods, https://doi.org/10.4324/9780203937877, 2007, 1-22.

25. Ghifari, Imam Fauzi. "Radikalisme Di Internet." Religious: Jurnal Studi Agama-Agama Dan Lintas Budaya, https://doi.org/10.15575/rjsalb.v1i2.1391, Vol, 1 No. 2, 2017, 13-134.

26. Anam, Khairul. "Radikalisme Di Dunia Maya : Menemukan Tuhan di Mesin Pencarian" Empirisme, Vol, 26 No.1, 2017,1-12.

27. Benedicta Dian Ariska Candra Sari. "Media Literasi Dalam Kontra Propaganda Radikalisme Dan Terorisme Melalui Media Internet." Peperangan Asimetrik, Vol, 3, No, 1, 2017, 15-31.

28. Achmad Zainal Huda. “Terrorism Studies Melawan Radikalisme Melalui Kontra Narasi Online." Journal of Terrorism Studies, Vol, 1No. 2, 2019, 1-15.

29. IPAC. "Mothers to Bombers: The Evolution of Indonesian Women Extremists," no. 35 (2017): 27. http://file.understandingconflict.org/ file/2017/01/IPAC Report 35.pdf, 2017, 1-15.

30. IPAC. "The Radicalisation Of Indonesian Women Workers In Hong Kong." Jakarta, 2017. http://www.understandingconflict.org/en/conflict/read/62/ The-Radicalisation-of-Indonesian-Women-Workers-in-Hong-Kong， 2017， 15.

31. Eko Saputra, "Menelisik Dinamika Radikalisme Gen Z Perempuan Di Facebook." ISLAMICA: Jurnal Studi Keislaman, https://doi.org/10.15642/ islamica.2019.14.1.103-125, Vol, 14, No. 1, 2019, 103-125.

32. IPAC. "Mothers to Bombers: The Evolution of Indonesian Women Extremists," $\quad$ http://file.understandingconflict.org/file/2017/01/IPAC Report 35.pdf, No. 35, 2017, 27.

33. IPAC. "Mothers to Bombers: The Evolution of Indonesian Women Extremists," $\quad$ http://file.understandingconflict.org/file/2017/01/IPAC Report 35.pdf, No. 35, 2017, 27. 
34. Dirga Maulana, "Situs-Situs Islam: Kontestasi Narasi Radikal dan Moderat." Convey Report Jakarta, Pusat Pengkaiian Islam dan Masyarakat (PPIM) UIN Syarif Hidayatullah, 2018, 8.

35. Dirga Maulana, “Situs-Situs Islam: Kontestasi Narasi Radikal dan Moderat.” Convey Report Jakarta, Pusat Pengkaiian Islam dan Masyarakat (PPIM) UIN Syarif Hidayatullah, 2018, 9.

36. Hanna Azarya Samosir. "Film Jihad Selfie, Mengungkap Alasan 'Remeh' WNI Gabung ISIS." Https://Www.Cnnindonesia.Com/. 2016. https://www. cnnindonesia.com/internasional/20160823083014-106-153170/film-jihadselfie-mengungkap-alasan-remeh-wni-gabung-isis

37. Dirga Maulana, “Situs-Situs Islam: Kontestasi Narasi Radikal Dan Moderat.” Convey Report Jakarta, Pusat Pengkaiian Islam dan Masyarakat (PPIM) UIN Syarif Hidayatullah, 2018, 15.

38. IPAC. "Mothers to Bombers: The Evolution of Indonesian Women Extremists, http://file.understandingconflict.org/file/2017/01/IPAC Report 35.pdf. No. $35,2017,27$.

39. Ihsan Ali-Fauzi, Zainal Abdin Bagir, Irsyad Rafsadi. Kebebasan, Toleransi Dan Terorisme Riset Dan Kebijakan Agama Di Indonesia. Jakarta: Pusat Studi Agama dan Demokrasi Yayasan Paramadina, 2017, 268.

40. Cunningham, Karla. "The Evolving Participation of Muslim Women in Palestine, Chechnya, and the Global Jihadi Movement." In Female Terrorism and Militancy: Agency, Utility, and Organization, https://doi. org/10.4324/9780203937266, 2007, 37.

41. Debra Zedalis, "Beyond the Bombings: Analyzing Female Suicide Bombers." In Female Terrorism and Militancy: Agency, Utility, and Organization, https:// doi.org/10.4324/9780203937266, 2007, 49.

42. Tessler, Mark. "Islam and Democracy in the Middle East: The Impact of Religious Orientations on Attitudes toward Democracy in Four Arab Countries." Comparative Politics, https://doi.org/10.2307/4146957, Vol, 34, No. 3, 2020, 337.

43. AWID (The Association of Women in Devolopment). Perempuan Dan Radikalisme Di Indonesia, Membangun Ketahanan Masyarakat Melalui Peran 
Perempuan. Jakarta: AWID, 2010.

44. Wahid Foudation. Intoleransi Dan Radikalisme Di Kalangan Perempuan. Jakarta: Wahid Foudation, 2018, 24.

45. Abdullah, Assyari. 2017. "Membaca Komunikasi Politik Gerakan Aksi Bela Islam 212: Antara Politik Identitas Dan Ijtihad Politik Alternatif." An-Nida: Jurnal Pemikiran Islam Vol, 41, No. 2, 2017, 202.

46. Sityi Maesarotul Qori’ah, "Keterlibatan Perempuan Dalam Aksi Terorisme Di Indonesia." Sawwa: Jurnal Studi Gender. https://doi.org/10.21580/ sa.v14i1.2967, Vol, 14 No. 1, 2019, 31-46.

47. Mupida, Siti. “Media Baru Dan Konflik Politik Islam Di Indonesia.”. http:// ejournal.uin-suska.ac.id/index.php/idarotuna/article/viewFile/8185/4327, Jurnal Idarotuna 2, no. 1 (2019), 14-26

48. Aarssen, L. W., \& Crimi, L. Legacy, leisure and the 'work hard-Play hard' hypothesis. The Open Psychology Journal, 9. Retrieved from aarssenl@ queensu.ca, The political psychology of terrorism fears, 2016, 213-226.

49. Abdurrahman, Muhammad Sufyan. 2020. “Generasi Muda , Agama Islam , dan Media Baru: Perilaku Keagamaan Gerakan Shift Pemuda Hijrah Bandung" Vol, 20 No. 1, 2020, 46-63.

50. M. Haqqi Annazilli, “Relasi Antara Agama Dan Media Baru.” Jurnal Ilmiah Syi'ar. https://doi.org/10.29300/syr.v18i2.1677, Vol, 18, No. 2, 2018, 26-44.

51. Najib Kailani, "Kami Adalah Mujahidin Berpedang Pena: Studi Gerakan Dakwah Forum Lingkar Pena Yogyakarta." Universitas Gajah Mada, 2009, 32.

52. Siti Mupida, "Wacana Generasi Muda Menuju Indonesia Emas 2045," Swarakampus.com, Yogyakarta, Aug-2020, https://swarakampus.com/ web/2020/08/04/wacana-generasi-muda-menuju-indonesia-emas-2045/, 2020, 1-2. 